\title{
Е.В. Какорина
}

Институт русского языка им. В. В. Виноградова РАН

(Россия, Москва)

kakor@yandex.ru

\section{ПРОБЛЕМЫ ФИКСАЦИИ И ЛЕКСИКОГРАФИЧЕСКОГО ОПИСАНИЯ КОММУНИКАТИВОВ (НА МАТЕРИАЛЕ РАБОТЫ НАД «ТОЛКОВЫМ СЛОВАРЕМ РУССКОЙ РАЗГОВОРНОЙ РЕЧИ» (ТСРР$))$}

Статья посвящена вопросам изучения коммуникативов и опыту их описания в современном Толковом словаре русской разговорной речи (ТСРР). Коммуникативы - слова-высказывания, неизменяемые слова или выражения, употребляемые в качестве реплик диалога (обычно ответных, реже - инициальных). Они представляют собой стереотипные реакции говорящего на предшествующие реплики или ситуацию общения. С формальной точки зрения - это застывшие выражения или ставшие неизменяемыми формы слов (часто имен или глаголов), развившие новое значение, связанное с оценкой ситуации или слов собеседника в диалоге. Коммуникативы не всегда фиксируются словарями, т.к. их трудно распознать и идентифицировать в устном диалоге в силу идиоматичности семантики, особой синтаксической роли и специфики грамматических признаков. Проблемы описания коммуникативов в словаре связаны с отсутствием единого взгляда на их грамматические свойства и характер выражаемого значения. Традиционно коммуникативы не выделяются в качестве самостоятельных языковых и лексикографических единиц. Они описываются в словаре как особые значения отдельных форм или значение какой-либо части речи, использующейся в функции частицы или междометия. Мы пытаемся показать, что коммуникативы могут стать полноправными единицами толкового словаря. Их семантика определяется через указание на тип речевого акта или интенцию говорящего, характер выражаемой оценки, а также

1 Толковый словарь русской разговорной речи. Вып.1: А — И / Авторы-составители: М. Я. Гловинская, Е.И. Голанова, О.П. Ермакова, А. В. Занадворова, Е. В. Какорина, М. В. Китайгородская, Л. П. Крысин, С. М. Кузьмина, И. В. Нечаева, А. Р. Пестова, Н. Н. Розанова, Р. И. Розина; отв. ред. Л.П. Крысин. - М., 2014; Толковый словарь русской разговорной речи. Вып. 2: К - О / Авторысоставители: М. Я. Гловинская, Е. И. Голанова, О.П. Ермакова, А. В. Занадворова, Е. В. Какорина, Л. П. Крысин, И. В. Нечаева, Е. А. Никишина, А. Р. Пестова, Н. Н. Розанова, Р. И. Розина, О. А. Шарыкина; отв. ред. Л.П. Крысин. - М., 2017. 
через описание прагматических условий реализации значения и просодических особенностей речи.

Ключевые слова: Коммуникативы, илллокутивы, устный диалог, лексикографическая практика, русская разговорная речь, толковый словарь разговорной речи, семантика и грамматика, лексикализация грамматических форм, способы толкования значения.

\section{1. Вводные замечания}

Единицы с идиоматичной семантикой широко распространены в разговорной речи. Среди них выделяются слова, функционирующие в качестве отдельных высказываний и приобретающие в диалоге нестандартные, отличающиеся от «словарных», значения. Данная статья посвящена проблемам выделения и описания единиц подобного рода, более точные характеристики которых будут обсуждаться далее.

Примеры:

- Как же ты мог сказать такое?!

- Молча! (Запись устной речи)

- Ну, как? Придете?

— И не подумаю// А еще пожалуюсь мужу, и он превратит вас... в крысу. (К/ф «Обыкновенное чудо»)

Носители русского языка, как правило, не ощущают формальной противоречивости смыслов выделенных слов, т.к. они употребляются не в своем прямом значении, их значение задается структурой диалога и легко вычитывается из контекста.

В первом примере ответное высказывание Молча! выражает уход от ответа, однако это не просто псевдоответ, а демонстрация того, что сам вопрос говорящий расценивает как неуместный или неправомерный. Эмфатическая интонация служит особому смысловому подчеркиванию и позволяет отличать данный коммуникативный тип высказывания от других. При таком употреблении Молча! в РР имеет синонимы Легко!; Вот так и...; Просто!; Запросто!; Изи!; На раз! и др.

В следующем примере мы видим, что ментальный глагол (в этой форме) также употреблен не в своем основном словарном значении. И не подумаю! означает категоричный отказ сделать то, о чём просит или к чему побуждает говорящего собеседник. Синонимами выражения И не подумаю! являются такие его соответствия: Ага!; Больно надо!; Вот еще!; Да пошел ть!; Держи карман шире!; Еще чего!; Ииь чего захотел!; Как же!; Ни за что!; Ну уж нет!; Облезешь!; Обойдешься!; Разбежался! Размечтался!; Спешу и падаю!; Только шнурки поглажу!; Щас! (Ща-а-с! Шаз!) и т. п.

Несмотря на широкую употребительность в РР слов и конструкций данного типа, они далеко не всегда становятся объектами лексикографического описания. 
Этому способствует их формально-структурное разнообразие, идиоматичность и семантическая разнородность. В настоящее время нет единства в понимании грамматического статуса подобных единиц, определении их синтаксической роли и способа описания их семантики.

В Толковом словаре русской разговорной речи, работа над которым ведется в отделе современного русского языка ИРЯ им. В.В. Виноградова РАН под руководством Л.П. Крысина, подобные единицы занимают оправданно важное место. На примере работы над ТСРР мы попытаемся показать, каким образом они описываются в словаре и с какими проблемами при их описании сталкиваются лексикографы.

\section{2. Проблема термина и определение объекта описания}

Приведенные выше примеры представляют не совсем стандартные единицы словаря. Разнообразие терминов, использующихся для их обозначения, говорит о различиях лингвистических подходов и точек зрения на предмет: междометия [Виноградов 1947]; частицьь и междометия [Шведова, 1960]; модальныле частиц̧ь и междометия [РГ 1980]; релятивы [Сиротинина 1974, Земская 1983]; коммуникемы [Меликян 1999]; речевые формульл [Баранов, Добровольский 2007]; иллокутивы [Кустова, 2012]; коммуникативы [Киприянов 1983; Колокольцева 1999; Шаронов 2015 и др.].

Мы будем называть слова данного типа коммуникативами. Этот термин, на наш взгляд, наиболее точно отражает их дискурсивную специфику и роль в устном диалоге.

Коммуникативы - это слова-предложения, реплики диалога, представляющие стереотипные ментальные или эмоциональные реакции говорящего на сказанное ранее, экспрессивную оценку действий собеседника или ситуации.

Важно подчеркнуть, что коммуникативы не создаются, а воспроизводятся в речи как готовые речевые формулы, принятые в определенных ситуациях общения (вопрос - ответ; предположение - подтверждение; просьба - согласие или отказ; оценка слов или действий собеседника и мн. др.).

В качестве коммуникативов могут выступать слова разных частей речи и словосочетания.

Примеры:

(Выражение восхищения:)

\section{— Ух ты! Вот это да! Вот это я понимаю! Умереть не встать!}

(Ситуация прощания:)

- Ну ладно/ Пока// Созвонимся!

- Ага// Давай!

(Предложение - отказ:)

- Завтра идем в кино?

— Обязательно! Ты с дуба рухнула? У нас зачет! 
(Просьба/ требование - отказ:)

[Сильва] - Гоните брюки/ вbl/ психи!

[Бусыгин] - Обойдёшься/ это тебе даже клищу! (К/ф «Старший сын»)

(Отказ на предложение третьих лиц и несогласие с утверждением собеседника:) [Женя] - Галя/ но с Катанянами всё-тки не очень хорошо...

[Галя] - Обойдутся! [Уходит] (К/ф «Ирония судьбы, или С легким паром»)

Коммуникатив Обойдешься! в абсолютивном употреблении выражает категоричный, грубый отказ выполнить просьбу или требование, а также косвенно негативно или пренебрежительно оценивает самого собеседника и при этом квалифицирует его просьбу как неуместную или не заслуживающую внимания. Коммуникатив Обойдутся! употребляется для выражения несогласия и отказа; при этом и отказ, и пренебрежение высказываются по отношению к нескольким лицам, не участвующим в разговоре.

Не все из приведенных выше слов фиксируются словарями в данных значениях. Отчасти это объясняется морфологическими и синтаксическими свойствами коммуникативов (это слова-высказывания, слова-предложения, специфика которых проявляется в устном дискурсе), а также, в определенной мере, - недостаточностью теоретических оснований для объединения столь разнородных фактов в единую самостоятельную группу языковых единиц. Дискуссия о лингвистическом статусе слов и выражений типа брось!, вали!, валяй! давай!, смотри!, куда там!, какое!; жуть!, блеск!, красота! и под. имеет достаточно продолжительную историю и остается актуальной до сих пор.

\section{3. Грамматические свойства, функции и семантика коммуникативов (из истории изучения)}

Основополагающие идеи об изменении лексической семантики и частеречной принадлежности слова под влиянием определенных синтаксических условий были высказаны в «Очерках по синтаксису русской разговорной речи» [Шведова 1960], где на основе анализа большого материала обсуждались факты перехода знаменательных слов или отдельных форм в разряд служебных слов (предлогов, частиц, союзов) и в междометия. Не менее важными для нас остаются идеи Д.Н. Шмелева, критически оценившего теоретическую и практическую целесообразность широкой трактовки служебных слов и междометий в рецензии на данную работу и в последующих статьях, посвященных «производным» служебным частям речи и междометиям [Шмелев 1961а; Шмелев 1961б].

Обсуждая идеи «отрыва» отдельной формы слова от общей парадигмы, приобретения ею особого значения и потери знаменательности в условиях употребления внутри особой грамматической конструкции, Д.Н. Шмелев занимал достаточно сдержанную позицию в вопросе о том, насколько уверенно можно при этом говорить о безусловном переходе слова в разряд служебных слов и утрате лексического 
значения: «...в языке постоянно происходит смещение значения определенных слов или отдельных грамматических форм, например, своеобразный отрыв и семантико-синтаксическое обособление некоторых падежных форм имени или некоторых форм глагола, перестающих быть соотносительными по своему значению и употреблению с другими формами данного имени или глагола $<$...> Обособленное употребление отдельной формы естественно смещает ее значение и нередко передвигает его за рамки общих значений данной части речи. Подобное движение может происходить в направлении к различным служебным словам <..> То, например, почему отдельные глагольные формы приближаются к частицам, а другие - к междометиям, зависит, как кажется, от природы самих этих форм, - причем именно как вполне определенных глагольных форм» [Шмелев 1961a: 499-500]. При этом Д.Н. Шмелев предлагает считать такие формы (например, формы повелительного наклонения валяй и т.п.) «обособившимися по значению формами»: «отдельные формы некоторых глаголов, утрачивая отчетливые очертания своего лексического и грамматического значения, могут в разных контекстах выступать в функции и частиц, и междометий и такой, которая не может быть подведена ни под какую рубрику классификации по частям речи (выделено нами - Е.К.); ср. употребление форм смотри - смотрите, гляди - глядите, брось - бросьте» [Там же: 504]. Та же позиция высказана и в отношении существительных — «значительной группы слов, включаемой в разряд междометий»: «Если считать междометиями cmpacmь, ужас, то с не меньшим основанием можно отнести к междометиям и другие существительные, выступающие иногда в разговорной речи с ярким экспрессивно-оценочным значением, сдвигающим их лексическое содержание, например: жуть, восторг, роскошь, блеск, красота, умопомраченье» [Там же: 503-504]. «Однако не кажется оправданным рассмотрение процессов «отрыва», синтаксического закрепления или контекстных «смещений» с точки зрения завершенного «перехода» знаменательных слов в служебные» [Там же: 505].

Идеи, высказанные в 60-70-е годы, получили новое развитие в последующей традиции. Исследования РР как одной из разновидностей русского литературного языка, которые велись в Отделе современного русского языка под руководством Е.А. Земской в 70-80-е годы, затрагивали и вопросы изучения коммуникативов (как синонимичные использовались термины «релятив» и «коммуникатив»). Е.А. Земская относила релятивы к классу неизменяемых знаменательных слов, представляющих собой нечленимые высказывания [Земская 1983: 84]. «Релятивы не имеют аналогов среди склоняемых и спрягаемых слов — частей речи» [Там же: 93]. Релятивами были названы либо фразеологизированные сочетания слов, либо «застывшие» формы слова, выделившиеся из общей парадигмы и получившие особое значение, это «осколки именных или глагольных парадигм», они отличаются от омонимичных словоформ знаменательных слов по функции и по семантике. Релятивы - это особый разряд морфологических единиц, которые начинают функционировать в качестве самостоятельных синтаксических единиц - отдельных высказываний. Их единственный оформитель - интонация. Их общее значение: «реакция на соседнюю реплику или ситуацию (выделено нами - Е. К.)» 
[Земская 1983: 92-93]. Ср. [Сиротинина 1974: 78]: слова, «употребляемые в речи с общим значением реакции на слова собеседника или ситуацию».

Обсуждавшиеся примеры релятивов включали фразеологизмы, незнаменательные слова, формы именного и глагольного, наречного, местоименного и др. происхождения: Подумать только! Ничего подобного!; Ну и что?; Чушь! Муть! Пустое!; Идет! (=согласен), Не скажи! (=не согласен), Скажешь!; Ладно!; Ничего!

Выводы:

— коммуникативы (релятивы) являются особым классом морфологических единиц;

- они функционируют только в устной речи, в «диалогическом режиме» в качестве «самостоятельных высказываний, единственный оформитель которых интонация»;

- они воспроизводятся в речи как готовые единицы;

- их типологические свойства - неизменяемость и нечленимость;

— они образуются путем «отрыва» формы от общей парадигмы и приобретения такой формой особого значения;

- коммуникативы обладают сложной семантикой, их общее значение: «реакция на соседнюю реплику или ситуацию» [Земская 1983: 93].

\section{4. Проблемы описания коммуникативов в толковом словаре}

Сегодня можно отметить активизацию интереса к изучению коммуникативов и постановку задачи их системного описания, составления словника и специальных словарей, см., например [Кустова 2012; Шаронов 2015, 2017]. При этом в центре внимания лингвистов вопросы определения семантики коммуникативов и способы ее описания в словаре.

\section{1. Распознавание коммуникатива}

Немаловажным и непростым оказывается вопрос идентификации, нахождения коммуникативов в тексте (дискурсе). Попробуем применить формальный (синтаксическая обособленность и неизменяемость), функциональный (функционирование в качестве самостоятельного высказывания) и семантический (сдвиг в семантике) критерии, опираясь на типологические свойства коммуникативов, которые были названы выше.

\subsection{1. Существительные и коммуникативы}

Неизменяемость грамматической формы и синтаксическая автономность служат первыми признаками комуникатива.

Ср. Жесть! Кошмар! Мрак! Ужас! 一 коммуникативы со значением общей отрицательной оценки ('нечто очень плохое') формируют самостоятельные 
высказывания на основе слова в единственно возможной форме - им. пад. ед. ч. (Коммуникатив Жесть! имеет и противоположное значение 'нечто очень хорошее').

В других формах слово реализует исходное значение - 'что-л. крайне неприятное или страшное' и/или то же значение общей отрицательной оценки. Это просто жесть/кошмар/ мрак/ ужас! Такой жести/кошмара/ ужаса никогда не видела!; Это было таким кошмаром!; Там был такой ужас! При этом существительные являются частью предложения (сказуемым, дополнением, подлежащим).

В ТСРР существительные, употребленные в функции предикатов, и коммуникативы с оценочным значением нередко (но не всегда) объединены в одной словарной статье.

\section{МРАК.}

DEF: выражает высокую степень отрицательной оценки или отрицательных эмоций. Вчера врачиха сказала ей, что токсикоз может длиться всю беременность - сорок недель! Мрак! Ей столько не выжить! (А. Житков. Супермаркет); <...> Остановки у нас — просто мрак! Вроде бы новый павильон, недавно поставили... Но видеть уродливые надписи неприятно (АиФ Смоленск, 03.08.2016) < ... >

(Автор словарной статьи Е.В. Какорина.)

Остается открытым вопрос о том, насколько правомерным является объединение толкования предиката и коммуникатива. $A$ платье обалдец! (предикат); Полный обалдец! Я в восторге// (коммуникатив). В ТСРР нередко значение оценки и выражение эмоциональной реакции не различается.

\section{ОБАЛДЕ́Ц.}

DEF: употребляется для выражения различных эмоций: восхищение, удивление, возмущение и т. п. (После просмотра кинофильма:) - Ну и фильмец-зашибеи мы с тобой посмотрели! - Полный обалдец! Я в восторге//; (Из разговора студенток:) - Мариш/ выглядишь классно! А платье обалдец! - Ага/ это я из Италии привезла// (Записи устной речи, 2013) < ... >

(Автор словарной статьи Н.Н. Розанова.)

Основанием для объединения толкования предиката и коммуникатива служит оценка какого-либо объекта, который не назван, но может быть легко восстановлен в позиции субъекта, хотя при этом, естественно, преобразуется структура высказывания: Фильмец - полный обалдец!

\subsection{2. Предикативы и коммуникативь}

К классу неизменяемых слов с обобщенным характером семантики, которая уточняется в условиях контекста и конситуации, в русском языке относятся и предикативы (ой-ё-ей, ни гу-гу, очень, (не) того, вообще, никуда и др.). Виноград по-моему очень даже// (хороший, вкусный); Виноград по-моему того// (испортился) [Земская 1983: 87-91]. На их основе строятся оценочные высказывания с ярко выраженной экспрессией. Ну ты вообще! Он вообще! Это было вообще! 
Предикативы определяются как неизменяемые знаменательные слова, выполняющие функцию сказуемого в личных высказываниях. В этом их отличие от коммуникативов, которые являются самостоятельными словами-предложениями (Ср. [Там же: 82]).

- Ну тыл вообще! (оценка, предикатив)

- Ну вообще! (оценка, коммуникатив)

Проблема разграничения коммуникативов и слов со сходными формальными и семантическими характеристиками (предикативами) особенно актуальна при составлении словаря, т. к. и предикативы, и коммуникативы нередко употребляются в значении общей отрицательной или положительной оценки.

Ср.: «Предикатив вообще (произносится [вашэ́] и [вапшэ́]) употребляется как сильная эмоциональная реакция, обычно для выражения резкой отрицательной оценки (возмущение, негодование, презрение и т.п.): Ну он вообще! ('зазнался', ‘воображает') С ним говорить нельзя!; Ты вообще! Куда ты это кладешь?» [Земская 1983: 88].

Критерием разграничения является разная структура предложения (синтаксическая автономность коммуникатива), а также сравнение синонимов:

- Ну он вообще! (идиот/ дурак... - характеристика лица, оценка характера, поступков, поведения - предикатив)

- Ну вообще! Ну класс! Ну потряс! Ну отпад! Ну жсесть! (оценка, эмоция коммуникатив).

\subsection{3. Глаголье и коммуникативь}

Описание коммуникативов, созданных на основе глагольных форм, также имеет свою специфику. В РР существует ряд синонимов: Забей! Забудь! Наплевать! Наплюй! Не бери в голову! Не парься! Ну и/ да ладно! Плюнь и разотри! Подумаешь! для переносного выражения смысла: 'не обращай внимания, перестань волноваться (по поводу чего-л.)', - совета или даже призыва к собеседнику не обращать внимания на нечто неприятное, не придавать большого значения какой-л. проблеме.

Слово Забей! вряд ли возможно интерпретировать как коммуникатив, если исходить из того, что переносное значение «перестать обращать внимание на что-л.» обнаруживается во всей системе его форм. Это отражено в словарной статье ТСРР глагола ЗАБИТЬ: одно из его значений определяется как «пренебречь чем-л., отказаться от чего-л.». Глагол в этом значении имеет управление на что. Я давно забил на это уже. Большинство же просто забивает на такие мелочи (Автор словарной статьи А. В. Занадворова). А как же остальные единицы ряда? Значение «отнестить с пренебрежением, проявить презрительное безразличие» отмечено в ТСРР у глагола НАПЛЕВАТЬ (На заключение это в штабе армии наплевали (А. Азольский. Облдрамтеатр). (Автор словарной статьи Л.П. Крысин.)

Мы помним, что в норме коммуникатив не может варьироваться (т. е. он реализует характерное для него значение в одной форме). Если же поставить на первое 
место значимость употребления в определенном типе речевого акта, а также учесть «довесок» или «сдвиг» значения формы повел. наклонения Забудь! и форм повел. и инфинитива Наплюй! Наплевать! — просьба или желание «не обращать внимание на неприятности, проблемы» (подобно своеобразному «увещеванию», уговариванию адресата) $)^{2}$, то можно отнести эти слова к коммуникативам (и, следовательно, необходимо отдельно описать их «коммуникативное» значение). Видимо, в каждом конкретном случае при принятии решения нам приходится учитывать разную степень «семантического выветривания» исходного значения и разный характер семантического сдвига, плюс степень обособления той или иной формы от общей парадигмы.

\subsection{4. Фраземы и коммуникативы}

В ТСРР фраземы-коммуникативы от других фразем отличает их синтаксическая автономность, использование в качестве самостоятельных ответных реплик в диалоге.

Коммуникативы, которые употребляются только как эмоциональные реакции говорящего на слова собеседника или ситуацию (единицы типа Держи карман uире!; Вот это да!; Ну вот ещзё!; Ну и ну! и под.), необходимо отличать от фразем, которые также могут участвовать в устном диалоге, выражая оценку слов собеседника или характеристику ситуации: Курам на́ смех!; Пиши пропало!; Ни боже мой и под.

Нередки примеры, когда «одна и та же» фразема функционирует как в составе высказывания, так и в качестве самостоятельной синтаксической единицы:

Какое (там) хорошо! Какое (там) отдохнуть! Какой (там) отдохнула! (=нет, не совсем так; совсем не так)

- Он правда был в Индии? - Какое (там)! (=совсем не так - несогласие говорящего со сказанным ранее).

Несмотря на синтаксические различия приведенных выше примеров, составители словарей склонны объединять подобные языковые факты.

Другой проблемой является выработка четких критериев, позволяющих разграничивать фраземы и свободные сочетания слов. Не всегда идиоматичность семантики и синтаксическая связанность дает возможность интерпретировать то или иное сочетание как фразему. Например, в ТСРР сочетание какое там подается как свободное сочетание в иллюстративной части словарной статьи КАКОЕ. В зоне SYNT помещен комментарий, уточняющий особенности синтаксического поведения частицы какое: «обычно в ответной реплике с безударным словом там» [ТСРР 2017: 26].

В процессе фиксации коммуникативов этого типа возникает также проблема вариативности фразем. Вариативность опорных и факультативных компонентов,

2 Отмечено в [Кустова 2012: 363] у коммуникативов брось! кончай! перестань! в изолированном употреблении без инфинитива. 
например в таких сочетаниях, как Какое там (mуm)! Куда там (mуm)! Где там (тут)!; Куда (уж) мне <нам, им и т. п.>!; Где (уж) мне <нам, им и т.п.>! и т. П., является фактором, затрудняющим если не идентификацию, то учет всего разнообразия семантически близких и/или имеющих общую формальную часть фраземкоммуникативов, существующих в языке.

Ср. примеры из ТСРР, фрагмент фразеологической зоны лексемы КУДА:

PHRAS: куда <уж> там! - 1) возглас, подчеркивающий невозможность сделать что-л. (обычно выражает разочарование, сожаление или иронию). Надеялись всё же перехватить относительно недорогие билеты с рук/ но куда там! (Запись устной речи, 2016).

(Автор словарной статьи Е. В. Какорина).

Синонимичные фраземы Какое там! Где там! не выделены в ТСРР. Однако в словарной статье лексемы ГДЕ фиксируется близкое значение местоимения, выступающего в функции частицы и употребляющегося в реплике-возражении собеседнику - «отрицание описываемой собеседником ситуации». - Cмотри вот/ диван сюда если/ вот так/ к окну вот/ тогда и икаф войдет// - Ну где войдет?! (Автор словарной статьи А. В. Занадворова.)

Учет всего объема фразем-коммуникативов возможен только в специальном словаре.

Ср. ряд коммуникативов из словарной статьи ДА.

PHRAS: вот это да! - выражает восхищение, восторг, удивление и т. п. - Bom это да, - выдохнула Женька, глядя на невероятный вырез у нее на спине (А. Геласимов. Дом на Озерной).

да ну? - выражает удивление, сомнение, недоверие. - Я видела такой микроскоп в магазине случайных вещей - четыре с половиной тысячи! - Да ну? Честное слово (Б. Кенжеев. Из книги счастья);

да ну тебя <вас, ее, их и т. п.> — выражает отказ от чего-л., несогласие с чем-л., осуждение и т.п. (может сопровождаться как бы отстраняющим жестом руки). Расскажи про наёмников, дядька Аптахар! - Да ну вас, - отмахнулся однорукий калека (М. Семёнова. Волкодав: Знамение пути); <...> Татьяна на правах подруги оборвала: - Да ну тебя с твоим телевизором! (А. Слаповский. Синдром Феникca);

ну да - выражает подтверждение сказанного, согласие со словами собеседника. — Bы там прописаньл? - допрашивала Ирина. - Ну да... (В. Токарева. Своя правда);

ну да? - то же, что да ну? - Говорят/ он всё это в одиночку перетаскал//— Ну да? (Запись устной речи, 2004).

(Автор словарной статьи Л. П. Крысин).

Обратим внимание на объединение в иллюстративной зоне фраземы да ну тебя <вас, eе, их и т. п.> высказываний разной (?) синтаксической структуры и не совсем совпадающих по значению (ср.: Да ну тебя!; Да ну тебя <на фиг и т. п.>! и Да ну тебя (с чем)! - Да ну тебя с твоим телевизором!), что отчасти объясняется принятыми в словаре формальными правилами описания фразеологизмов, а также 
еще раз говорит о неоднозначности интерпретаций и трудностях фиксации единиц данного типа.

\section{Выводы:}

Мы видим, что примененные нами критерии не вполне обеспечивают «узнавания» и идентификации коммуникатива. Вариативность в фиксации и толкованиях значений коммуникативов характерна для современной лексикографической практики в силу «необщепринятости» взгляда на данный, синкретичный по своей природе класс слов, разнородных по своему происхождению, обладающий, тем не менее, признаками единства формы, функции и семантики.

\section{2. Разграничение коммуникатива и слова с полной парадигмой}

Для разграничения эллиптичных конструкций, слов в абсолютивном употреблении и коммуникатива как отдельной формы слова в особом значении можно использовать еще один критерий - перевод текста из диалогического в повествовательный режим, перефразирование высказывания через косвенную речь.

Г.И. Кустова, предлагая рассматривать коммуникативы (иллокутивы) с точки зрения специфики выражения экспрессивной и апеллятивной языковых функций, показывает, что им не свойственна дескриптивная («повествовательная», информационная, репрезентативная) функция языка: «иллокутивы - это знаки актуального самовыражения или актуального воздействия, именно поэтому они не переводятся в описательно-повествовательные структуры и не имеют других форм» [Кустова 2012: 355].

На это впервые, по-видимому, указал И. А. Шаронов, предложив тест для идентификации коммуникативов. Существуя только в устном диалоге, коммуникатив исчезает при переводе высказывания в косвенную речь.

- У меня машина сломалась! - Поздравляю!;

- У меня машина сломалась! — * Он поздравил меня!;

- Поздравляю! (= ироничная реакция на плохую новость);

Это же Альпьл. - Это - Альпь?? Не может быть! - Здрасьте, приехали. А что же, по твоему? - Нет, скажи ему, это ж не Альпь. - Да, - сказал Щу-

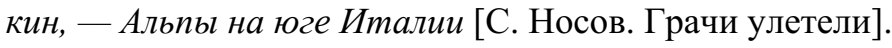

Это же Альпьл. - Это - Aльпьл? Не может быть! — * Он поздоровался.

Здрасьте! (=удивление, возражение, недовольство, перебив).

«При такой операции коммуникатив целиком, без остатка заменяется на предикаты со значением интенции, ментального или эмоционального состояния говорящего. Например, то-то и оно - заменяется на: подтвердить что-л.; еще чего - на отказать в чем-л.; ни боже мой - на отрицать что-л.; так уж и быть на разрешить что-л.; креста на тебе нет! — на осудить кого-л. за что-л, или на обвинить кого-л. в чем-л. и т. д.» [Шаронов 2009: 544]. Таким образом, идентифицируя 
коммуникатив, мы можем заменить его на имя речевого акта или указание на интенцию говорящего. Ср.:

- Ой, какая красивая! Обалдеть! (=оценка)

— Чё так дорого? Обалдела? С ума сошла? (=укор)

- Чай будешь? - Можнол// (= «Да») - Спрашиваешь! (=уверенное согласие).

- Налей чайку! - Обойдешься! Облезешь! Размечтался! Спешу и падаю! (=отказ)

Выводы:

- коммуникативы не переводятся в косвенную речь;

- при переводе высказывания в косвенную речь (нарративный тип текста) коммуникатив исчезает, его можно заменить на предикат, обозначающий интенцию говорящего, имя речевого акта или указание на выражаемую эмоцию.

- Можно мне ... - Облезешь! ( *Он сказал, чтобы я облез/ Он мне отказал/ Он мне грубо отказал (ср.: Он меня «послал»)).

\section{3. Вид входного слова}

Проблема определения входного слова для словарной статьи связана с типологическими особенностями коммуникатива.

Если коммуникативы - это «осколки» парадигмы, которые омонимичны остальным формам, т.к. они изменяют грамматические и лексические значения и становятся самостоятельными лексическими единицами, то логично делать коммуникативы отдельными единицами словника, т. е. выделять их в качестве заголовочных слов, посвящая им соответствующие словарные статьи. Однако в лексикографической практике мы учитываем разную степень отрыва (и соотнесенности) с остальными формами парадигмы, а также, вероятно, в значительной степени просто следуем традиции, помещая коммуникатив в словарную статью другого слова. При этом, безусловно, существуют переходные случаи употребления языковых единиц, претендующих на роль коммуникативов, изменяющих или не изменяющих свой грамматический статус. Понятно, что существительные в им. пад., наречия, частицы и междометия могут «законно» оформляться как отдельные слова, однако современная лексикографическая традиция этому скорее препятствует, так, например, значения частицы давай(mе) описываются в словарной статье глагола давать (ТСОШ). Вынести отдельную глагольную форму (Обойдешься!; Наплюй! и т.п.) в позицию заголовочного слова представляется еще более рискованным, тем более что иногда все же возможна вариативность форм (Hy, mbl даёшь! Hy вы даёте! Ну он даёт! Ну они дают! (=оценка); Не спи! Не спите! (=побуждение к более интенсивному действию). На наше решение о способе подачи коммуникатива в словаре влияет не только различная степень отрыва от глагольной парадигмы, переход в другую часть речи и характер семантической трансформации значения (Ну давай! (в ситуации прощания) — междом. и Hy, даёшь! [стране угля] (оценка) - форма гл.), но и лексикографическая традиция. В тех же случаях, когда формы глагола являются разными коммуникативами (Hy mы подумай! 
(=удивление); Подумаешь! (=пренебрежение); Скажешь тоже! (=укор, возмущение, категоричное несогласие); Не скажи! (=несогласие, часто неуверенное)), их значение, на наш взгляд, логичнее и удобнее было бы описывать в отдельных словарных статьях.

Примеры из ТСРР. Два разных слова - существительное и коммуникатив (существительное, употребляемое в значении междометия) - подаются как два омонима:

\section{МА́МОЧКА ${ }^{1}$.}

DEF: ласковое название матери. Поздравляю твою мамочку, Мариш!; Когдато здесь, в ЖЖ, одна мамочка просила совета и жаловалась на то, что ее сына задирают в иколе (Блоги, 2014)...

MORPH: ж.; одуш.

\section{МА́MОЧКА ${ }^{2}$ !}

DEF: возглас, выражающий сильные эмоции (удивление, ужас, боль и т. п.). И они эту дверь задвинули/ и там все прыг... - Ой/ мамочка/ я представляю шо там случилось// (Из коллекции НКРЯ, 2008); - Ой, мама, мамочка... куда же я попал? (Е. Хаецкая. Синие стрекозы Вавилона)...

MORPH: сущ. в знач. междом., ж.

(Автор словарных статей А.В. Занадворова.)

\section{КЛАСС.}

$\mathrm{DEF}$ : высокий уровень мастерства, умения или каких-л. положительных свойств. Это/ конечно/ высший класс// Я так не смогу// (Запись устной речи, 1999); Ну давай/ покажи класс/ раз ты такая крутая// (Из материалов Ульяновского университета, 2007)...

MORPH: $\boldsymbol{\mu}$.

SYNT: чего или без доп.

\section{КЛАСС!}

DEF: очень хорошо. - Во Франциию ездила// - Когда? - В марте// - Класс! Сколько стоит путевка? (Из материалов Ульяновского университета, 2007); (О машине:) Класс! Отец недавно купил/ почти новая// (К/ф «Исчезнувшая империя», 2008)...

MORPH: сущ. в знач. междом.

(Автор словарных статей М. Я. Гловинская.)

Однако, как правило, в ТСРР значение коммуникатива описывается внутри словарной статьи существительного, например, в статье КОШМАР - это один из вариантов второго значения. В этом случае в особой зоне словарной статьи отмечается, что слово употребляется в качестве самостоятельного высказывания.

\section{КОШМА́Р.}

2. DEF: о чём-л., вызывающем сильные отрицательные эмоции. Справочная всё время была занята. - Кошмар! - простонал профессор. - Цельий час - всё занято (В. Шукшин. Печки-лавочки); ...На работе у них - тихий ужас, кошмар! Все сидят «на чемоданах» - то ли закрывают их, то ли нет (Блоги, 2013); Поздно 
вечером заявился// Ну совсем пьяный// Двух слов связать не может// Просто кошмар!; В прошлом году/ в это время/ у нас такие морозы стояли! Прямо кошмар! (Записи устной речи, 2011, 2012).

MORPH: м., только им. ед.

SYNT: употр. в составе сказуемого или как самостоятельное восклицательное предложение междометного характера, часто в сочетании со словами $к а$ кой, просто, прямо.

STYL: неодобр.

SYN: жуть (во 2 знач.), ужас.

ANALOG: надо же, ну и ну, страсть, страх, с ума сойти (см. ум).

(Автор словарной статьи Е.И. Голанова.)

В ТСРР представлена лексема ДАВАЙ, которая подается и как частица, и как междометие (в одном из междометных значений слово является коммуникативом). Это значение не отмечено другими словарями.

\section{ДАВА́̆̆̆, ДАВА́ЙТЕ.}

3. DEF: употребляется как формула прощания, как знак окончания общения. Ну, давай, разбегаемся: мне по делам, а ты - куда хочешь (М. Чулаки. Примус); - Ну, давай, - он повернулся ко мне и протянул руку (А. Геласимов. Год обмана); Шурин голос вдруг погрустнел. - Давай. На службу опаздьваю (А. Волос. Недвижимость); (Муж, уходя на работу:) - Закрой за мной// Ну давай// Пока// Пока/; - Ну всё/ я ушла// Там на плите рис с индюшкой/ в холодильнике суп// Ешьmе// — Ну давай// За квартиру заплати// Пока// (Записи устной речи, 2011).

MORPH: междом.; обычно только в форме ед. (давай).

SYNT: часто после частицы ну (ну, давай!).

STYL: сниж.

SYN: бывай, пока, счастливо, чао.

У глагола ДАВАТЬ фиксируется «коммуникативное» значение оценки. В иллюстративной зоне приводятся формы Hy, mbl даёшь! Hy вы даёmе! Ну он даёm! Ну они даюm!, которые образуют высказывания-коммуникативы.

\section{ДАВА'ТЬ'.}

4. DEF: употребляется как средство оценки каких-л. действий, вызывающих у говорящего удивление, возмущение, восторг, радость и т.П. Так и хочется воскликнуть: «Ну вы, ребята, даёте!» (За рулем, 15.03.2004); - Что, всё ещё не куришь? - хмыкнул он. - Ну ты даёшь, Володька! Никой чёрт тебя не берёт! (В. Белоусова. Второй выстрел); Папа обхватит мой бицепс и удивленно покачает головой, мол, ну ты даёшь! (М. Шишкин. Письмовник); - Когда активирована функиия защчтть от детей, нельзя выключить холодильник. - И только? Блин, ну они дают, хоть в инструкиии бы написали об этом (Блоги, 2012).

MORPH: несов.; сов. (дать) малоупотр.

SYNT: в контексте с местоимениями $m b l$ или вbl, часто с предшествующим междометием $н y$. 
Данное значение реализуется только в формах 2 и 3 лица ед. и мн. числа настоящего и прошедшего времени. На ограничения в образовании форм справедливо указывает Г.И. Кустова [Кустова 2012: 353].

\section{4. Фонетический облик слова-коммуникатива в словаре}

Проблема графического представления коммуникативов в словаре возникает по причине развитой вариативности их фонетического облика в РР, с одной стороны, и отсутствия традиции графического оформления таких слов - с другой.

В устном диалоге большое значение имеют просодические средства выражения экспрессии: модификация интонационного контура, выделение голосом опорного слова, растяжка, удлинение гласных; в то же время отмечаются различные виды фонетического эллипсиса в сильной фразовой позиции и другие фонетические деформации слова.

В каких же случаях необходимо отражать фонетический эллипсис и фонетические деформации, возникающие в узусе? Вероятно, в тех случаях, когда они отражают разговорную произносительную норму. Это такие фонетические деформации, которые говорят о сдвигах в семантике или в грамматическом статусе слова, а также - наиболее частотные произносительные варианты слов, превратившиеся в разговорные «лексические дублеты» слов КЛЯ (сейчас - щас, вообще - вопщุe, воще, сегодня - сёдня, человек - чек и мн. др.). О лексикализации разговорных произносительных вариантов слов и их лексикографическом представлении см. [Розанова 2015].

Коммуникативы активны не только в устном общении, но и в интернет-коммуникации, совмещающей в себе признаки устного и письменного общения. При этом в текстах интернет-коммуникации, узаконившей случаи намеренного искажения слова и языковой игры, нередко представлены факты «стихийного» отражения вариантов разговорного произношения слова в письменном тексте. Понятно также, что круг «разговорных дублетов» слов КЛЯ в интернет-общении шире, чем в других сферах письменного общения. Приведем примеры частотных коммуникативов, отражающих различную степень редукции и перестройки исходного слова или выражения:

Ни фига себе! Фига себе! Фигасе! Фигас!

Ничего себе! Ничёсе! Ничоси!

Счаз! Щас! Ща-а-з!

Ну вообщее! Hy вапщฺе! Hy ващче!

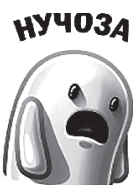

В первом случае преобразование коммуникатива приводит к упрощению фраземы до одного слова, при этом Фигас! может осмысляться как существительное мужского рода, способное склоняться.

Носители языка и особенно участники интернет-коммуникации очень восприимчивы к таким преобразованиям слова в речи, особенно в публичном интернетобщении, ср. интернет-мемы, возникшие на основе мема «Ничоси», использующего для выражения крайней степени удивления. 


\section{Ни40СИ}
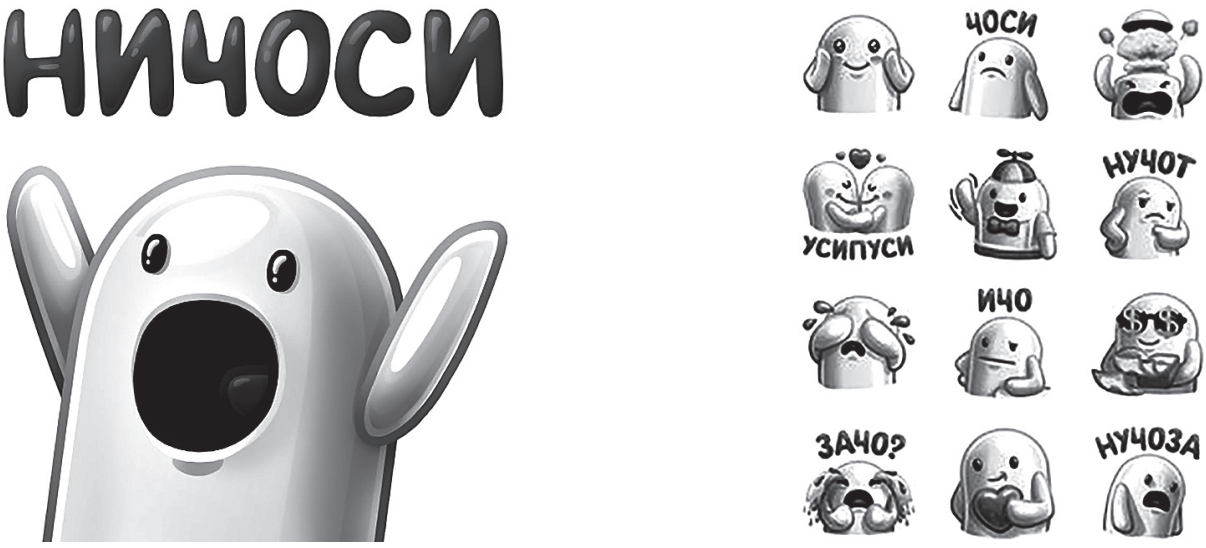

Подобные тиражируемые в узусе факты нередко превращаются в языковую игру, становятся моделями для созданий новых слов, служат своеобразной формой для лексически ёмкого представления различных смыслов (ничёси - бабоси - чаёси - нажрёмси). Ср. мемы:

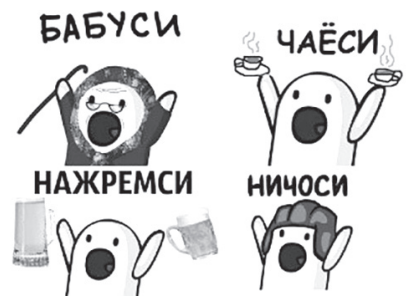

Словарь отражает наиболее частотные варианты, случаи устоявшегося преобразования, редуцирования слова.

Пример из ТСРР (автор словарной статьи - Н. Н. Розанова):

ничего себе - выражает удивление, восхищение, недоверие, несогласие и т. п. - Мы сегодня радугу видели/ представляете? - Ничё себе! Здо́рово// (Разговоры дома // Из коллекции Ульяновского университета, 2009).

Пример проекта словарной статьи со входом ЩАС. (Автор статьи Н.Н. Розанова.)

ЩАС.

6. DEF: выражение несогласия с говорящим. - Я думаю он (мастер) сегодня позвонит// -Пря-а-м/ Ща-а-с! С чего это вдруг?; -Щас по-моему подержанные иномарки подешевели// -Ага/ ща-а-с/ размечталась// (Записи устной речи, 2010); Вот говорят: «Напилась - веди себя прилично!» Ага, щас! На фига я тогда вообще пила!? (Блоги, 2014).

MORPH: модальная частииа.

STYL: ирон.

SYN: в сочетании со словами: прямо, прям, разбежался, как бы не так, ещё чего. 
PRAGM: обычно произносится как [ш’ас], несмотря на сильную фразовую позицию. Ироническое отношение говорящего к словам собеседника выражается фонетическими средствами - удлинением ударного гласного или заменой глухого конечного согласного звонким: щза- $a-c$, щзаз-з.

Приведенные примеры графического оформления коммуникативов в ТСРР призваны скорее обозначить проблему последовательного отражения характерных для РР фактов редукции слова при существующей лексикографической традиции игнорировать подобные разговорные лексикализованные эквиваленты слов КЛЯ.

\section{5. Грамматическая характеристика слова}

Вопрос о том, какова морфологическая характеристика коммуникатива, остается дискуссионным.

Он определяется как частица или междометие (Н.Ю. Шведова), та или иная часть речи в функции частицы или междометия (Д.Н. Шмелев), особый класс неизменяемых знаменательных слов - релятивов (коммуникативов) (Е.А. Земская). Термины «коммуникатив», «релятив» не были приняты в ТСРР в силу адресованности словаря не только филологам-специалистам.

В зависимости от конкретных особенностей употребления того или иного коммуникатива, в словаре возможны варианты морфологической квалификации этих слов.

КОШМАР. MORPH: м., только им. ед.

КЛАСС. MORPH: сущ.. в знач. междом.

MPAK. MORPH: междом.

Типологические признаки коммуникатива как слова-высказывания находят отражение в зоне помет, где дается информация о морфологической и синтаксической характеристике слова.

МРАК.

DEF: выражает высокую степень отрицательной оценки или отрицательных эмоций.

MORPH: междом.

SYNT: часто употр. как отдельное высказывание, а также со словом просто.

\section{ОБАЛДЕ́ТЬ.}

2. DEF: прийти в состояние изумления, восхищения, восторга.

MORPH: сов.; несов. обалдевать.

SYNT: om чего или без доп.; в абсолютивной позиции, без зависимых форма инфин. с восклицанием употр. в функции междометия (Обалдеть!). 


\section{6. Описание значения коммуникатива в словаре}

В настоящий момент вопросы определения семантики коммуникативов остаются не до конца решенными. Одни исследователи говорят об «иллокутивном сдвиге» исходного значения в сторону идиоматичности (непрозрачности), другие полагают, что им свойственна сильная «десемантизированность» и «денотативная пустота» [Шаронов 2017: 116; Шаронов 2015: 147].

\subsection{1. Характер семантического сдвига}

Коммуникативам свойственна различная степень утраты мотивированности значения, ср.:

Рискни! Попробуй! (=не делай этого!); Не бери в голову! Плюнь и разотри! Не парься! Забей! (=не обращай внимания); Облезешь! (=грубый отказ); Обалдеть! Умереть не встать! Опупеть! Это что-то! (=восхищение).

«С точки зрения семантики рассматриваемые формы претерпевают сдвиг значения в сторону большей или меньшей идиоматичности: у каких-то иллокутивов (ср. Хватит! Прекратите! Берегись! 'угроза') семантические изменения более прозрачны, т. к. основаны на импликациях, у других (оценочное значение у Сойдет и Зашибись, угроза у Смотри [, дождешься у меня], согласие у Идёт) эти изменения не имеют столь очевидной мотивировки и не выводятся прямо из исходного значения глагола» [Кустова 2012: 352].

Данное свойство коммуникативов связано с их опорой на контекст и конситуацию.

\subsection{2. Толкование «нестандартной» семантики}

Коммуникативы нередко трактуются как «единицы, которые не передают номинативного содержания (выделено нами - Е.К.), а служат для формирования общих представлений и оценок собеседников относительно предмета обсуждения» [Шаронов 2015: 142], факты «недескриптивного использования языковых форм» [Кустова 2012: 354]. Их семантика связывается, как уже говорилось, с реакцией собеседника на соседнюю реплику или ситуацию. Но в чем эта реакция выражается и из каких компонентов она состоит? Какие компоненты ситуации общения должны быть включены в толкование?

Коммуникативы сближаются с междометиями, которые используются «для нерасчлененного выражения чувств, ощущений, эмоциональных и эмоциональноволевых реакций на окружающую действительность» (АГ-80) и лишены номинативного значения. Однако коммуникативы значительно более, чем междометия, разнородны по составу и сложны по семантике. Они создаются на основе незнаменательных и знаменательных слов и фразеологизмов, их значение реализуется поразному, в зависимости от контекста и конситуации. Можно определять семантику коммуникативов, исходя из конкретной ситуации: 
«Некоторые релятивы наделены сложной, многокомпонентной семантикой: Н. Это ты чашку разбил? О. Ну и что? (Согласие с оттенком вызова; приблизительно: 'Я не отрицаю, что разбил, но зачем возмущаться, мало ли что бывает') [Земская 1983: 93].

Ср. также описание семантических разновидностей восклицательных реплик эмфатического отказа Как же! Вот ещуе! Еще чего! Щас! и др. в [Крейдлин 2006].

Однако подходы, применяемые в специальных исследованиях коммуникативов, не могут использоваться при их описании в толковом словаре.

Представляется, что, поскольку коммуникатив определяется как слово-предложение (т. е. он является высказыванием), то и толковать его нужно как высказывание - через отсылку к имени речевого акта, указание на интенцию или выражаемую эмоцию (оценку). Очевидно, что эта обязательная часть толкования может дополняться вариативной частью.

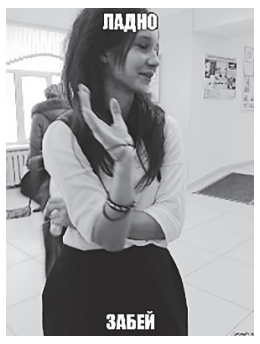

Существенно важными для алгоритма описания коммуникатива являются такие коммуникативные параметры, как характер предыдущей реплики, апелляция к собеседнику или отсутствие таковой и мн. др., что определяет семантику и смысловые различия синонимичных коммуникативов, прагматические условия реализации данного значения, а также просодические характеристики (например, особенности произношения: Же-е-сть!), и другие паралингвистические характеристики диалога (интонация, жесты, мимика).

Примеры из ТСРР:

НУ'.

1. DEF: употребляется для выражения побуждения, призыва к чему-л. (На прогулке. Мать 6-летней дочери, боящейся перепрыгнуть через небольшую лужу:) Ну! Ксеня! Ну же! Прыгай/ не бойся!; - Наливай давай// - Салатик возьми// — $\boldsymbol{H y / ~ з а ~ п о б е д у / / ~ ( К / ф ~ « А ~ п о у т р у ~ о н и ~ п р о с н у л и с ь » , ~ 2 0 0 3 ) ; ~} \boldsymbol{H y - c ~ / ~ т о в а р и щ ~ в е с е л ь ч а к / ~}$ пожалуйте на лобное место// (К/ф «Большая перемена», 1973) < ... >

MORPH: междом.

SYNT: обычно перед глаголами в повелительном наклонении, обращениями, словами давай, пожалуйста, прошу вас (тебя), же и т. п.; может употребляться как самостоятельная реплика (с восклицательной интонацией); может употр. с частицей -с - обычно с оттенком шутки, иронии или при стилизации старой интеллигентской речи.

SYN: валяй (cм. валять), давай, давайте (в 1 знач.), нуте (в 1 знач.), нуте-ка, нутка.

3. DEF: используется для выражения разных видов эмоциональной реакции на чьи-л. слова, действия или события - радостного согласия: (Рассказывает о своем предстоящем выступлении в телевизионной программе:) - A вы по те́лику смотрите потом [мое выступление]// - Нy-y! Обязательно!; недовольства: - Погода 
отвратительная! До чего ж надоела эта слякоть! Прям удавиться хочется// Ну уж! Скажешь тоже//; сомнения: - Эти чиновники все продажные/ все взяточники// - Ну-y/ пря-а-м// (Записи устной речи, 1998, 2012, 2013); недоверия: Макашов говорят застрелился// - Ну! - Вот мужчина говорит// (Из разговора на митинге 04.10.1994); Ну! Нy! Нy! Нy! / Врешь! Врешь! Врешь! Врешь! (Д. Хармс. Врун); восхищения: (О победе сборной России по хоккею:) Нy, ребята! Ну молодųь!! Поздравляю с победой! (Блоги, 2012).

MORPH: междом.

SYNT: может употребляться в сочетании с частицами да, прям, уж и др.

SYN: ага, ай, ай-ай, ай-ай-ай, ах (в 1 знач.), во, вот, вот так (cм. вот), ни фига себе (см. фиг), ничего так (см. ничего), ничего себе (см. себе), ого, ого-го, ой, ух, ух ты (cм. ух), эх...

(Автор словарной статьи Н.Н. Розанова.)

В приведенном ниже примере в толковании из ТСРР описывается ситуация общения, названы интенции собеседников, учитывается левый контекст: тип предшествующей реплики - недоуменный вопрос. Такой вопрос нередко задается с возмущением, восклицательной интонацией, которая характерна и для ответной реплики. Несогласие говорящего с оценкой ситуации, содержащейся в репликестимуле, и уход от ответа в данном случае выражается, помимо интонации, семантическим перебивом, сдвигом в значении.

\section{МО́ЛЧА.}

DEF: ответная реплика на недоуменный вопрос «как? (каким образом?)», которая выражает (вместо ответа) демонстративный отказ собеседника согласиться с тем, что то, о чём спрашивают, является ненормальным, затруднительным, странным и т. п. - Ну как же ты мог сказать такое? - Молча! (Запись устной речи, 2014); - Дурак/как же я кроссовки снимать буду! - Молча// [смеется] (Разговор двух школьников// Из материалов Ульяновского университета, 2007); - И тогда он предложил мне стать его женой! - Как это он предложил?-Молча... (К/ф «Блондинка за углом», 1984); —Хорошо, но как всё-таки удалось ещё и авторитет завоевать, чтобы претендовать на директорское место? - Ой, да никак,смеётся сама Кириченко. — Молча (Труд-7, 25. 04.2002) <...>

(Автор словарной статьи Е. В. Какорина.)

\subsection{3. Омонимия и многозначность коммуникативов}

В силу развитой омонимии и многозначности коммуникативов перед составителями нередко вставала необходимость разграничения их значений. Например, в ТСРР у междометия $A$ (коммуникатив) в ТСРР отмечено три, у частицы $A-$ четыре значения. У разговорного междометия $H y$ зафиксирововано три значения, а частица $H y$ описана в одиннадцати значениях.

Немотивированность значения, зависимость от контекста, отсутствие «видимых» формальных признаков (грамматических показателей) слова, ирония 
и энантиосемия, характерные для многих коммуникативов, создают трудности для понимания этих слов иностранцами, изучающими русский язык. Описание данных единиц в ТСРР может служить ключом к их интерпретации и являться помощью для корректного использования коммуникативов в речи. Ср.: «Ладно!» больше всего бесит иностраниев// Они думают что это «да» а на самом деле это «нет»// (Запись устной речи, 2018).

\section{7. Парадигматика}

Показательны большие синонимичные ряды, использующиеся для выражения того или иного «коммуникативного» значения. Ср. выражение высокой степени положительной оценки (удивления и /или восхищения):

Блеск! Вот это да! Жесть! Зашибец! Зашибись! Клёво! Класс! Красота! Круто! Мама! Мама дорогая! Мама миа! Ни фига! Ничего себе! Ничёсе! Ништяк! Ну и ну! Обалдеть! Ого! Опупеть! Отпад! Охренеть! Под столом! Потряс! С ума сойти! Супер! Улёт! Умереть не встать! Фантастика! Фигас! (Фига себе!) Чтото с чем-то! Шик! Это что-то! Я не могу! Я в шоке!..

ТСРР фиксирует синонимы, аналоги и антонимы которые помещаются в соответствующей зоне словарной статьи.

\section{МАМОЧКА ${ }^{2 !}$}

DEF: возглас, выражающий сильные эмоции (удивление, ужас, боль и т. п.).

SYN: мама' $a^{1}$, мама дорогая (cм. мама $\left.{ }^{1}\right)$, мама родная (cм. мама $\left.{ }^{1}\right)$, мамочки!, матушки!, мать моя женщина (cм. мать²), мать честная (cм. мать $\left.{ }^{2}\right)$.

ANALOG: батюшки!, боже!, боже мой!, господи!, ой.

(Автор словарной статьи А. В. Занадворова.)

\section{ОБАЛДЕ́ТЬ.}

2. DEF: прийти в состояние изумления, восхищения, восторга.

SYN: абзац, зашибец, пипец, трендец.

ANALOG: балдёж, зашибись (в 1 знач.), класс, офигеть, охренеть, потряс, потрясно...

(Автор словарной статьи Н.Н. Розанова.)

Вариативность может касаться не только наполняемости «тематического» ряда, но и формы синонимичных по значению коммуникативов. Ср. выражение удивления, восхищения, возмущения:

Обалдеть! Обалдец! Опупеть! Офигеть! Офонареть! Охренеть! Очуметь!

У нас у Ани такое слово в лексиконе есть замечательное - «обалдец» (это она скрестила обалдеть и капеи). Идём в пятницу по улице, она что-то увидела и вся в возмущении на всю ивановскую: «Ваще обалдец!» (Форум «Наши дети», 19.04.2012).

Случаи игрового варьирования коммуникативов обычно не отмечаются словарем. Узуальность подобного слова с обыгрыванием формы служит основанием для 
включения коммуникатива в словарь, однако этот вопрос не всегда имеет однозначное решение. Ср. примеры коммуникативов для выражения согласия: Ладно!; Лады!!; Ладушки!; Ладныть!, среди которых только первые два слова включены в словарь.

\section{8. Прагматическая характеристика}

В РР интонация нередко выполняет смыслоразличительную функцию. Значимость фразового ударения, интонации и других произносительных особенностей определяется семантической и грамматической природой коммуникатива. В ТСРР информация такого рода помещается в разных зонах словарной статьи (в толковании или в зоне PRAGM (см. примеры выше)).

$\mathbf{A}^{1}$.

2. DEF: указывает на неожиданное узнавание кого или чего-л, на понимание какого-то высказывания, на осознание истинного положения дел или припоминание чего-л. (часто произносится с растяжкой). $\boldsymbol{A} /$ здесь дом (К/ф «Зеркало», 1974); - Ира? Ть что это дома сегодня? - Да я на работу не пошла/ дома работаю// - A-a / а то я уж подумал/ может заболела// (Телефонные разговоры, 1991-

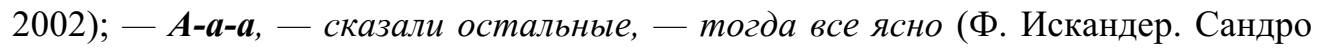
из Чегема).

MORPH: междом.

SYNT: в начале высказывания или перед ним как отдельное высказывание.

SYN: o!

3. DEF: используется для выражения различных эмоций - пренебрежения (произносится кратко и энергично или растянуто): A! Мало ли что она говорит!; досады (произносится кратко, отрывисто, на энергичном выдохе): $\boldsymbol{A}$ / черт/ ключи

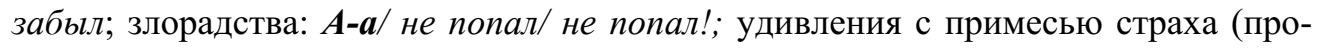
износится с растяжкой, на вдохе): $\boldsymbol{A - a - a / ~ о н ~ з а б ы л ~ б и л е т ~ д о м а ; ~ ф и з и ч е с к о г о ~ у д о - ~}$ вольствия (произносится глухо и напряженно, с энергичным выдохом): A/xорошо! Поддай ещзе пару! (Записи устной речи, 2002-2009).

MORPH: междом.

SYNT: в начале высказывания.

(Автор словарной статьи М. Я. Гловинская.)

Концепция ТСРР как словаря экспериментального типа допускала вариативность при описании коммуникативов. Словарное представление этой группы слов связано с недостаточной «укорененностью» в традиции и с неоднозначностью существующих теоретических взглядов на их лингвистический статус и их типологические характеристики.

Коммуникативы, на наш взгляд, должны стать полноправными лексикографическими единицами, более широко и последовательно фиксироваться в словарях разговорной речи и в толковых словарях современного русского языка, что позволит в дальнейшем более точно и полно описывать их семантику. 


\section{Литература}

Баранов А.Н., Добровольский Д. О. Фразеологический объяснительный словарь русского языка. М., 2009.

Виноградов В. В. Русский язык. Грамматическое учение о слове. М., Л., 1947.

Земская E. A. Морфология // Русская разговорная речь. Фонетика. Морфология. Лексика. Жест. М., 1983. С. 80-118.

Киприянов $B$. Ф. Проблема частей речи и слова-коммуникативы в современном русском языке. М., 1983.

Колокольщева Т. Н. Антропоцентризм диалога // Вопросы стилистики. Вып. 28. Саратов, 1999. С. 114-125.

Крейдлин Г.Е. Эмфатические ответные реплики в диалоге // Русский язык сегодня. Вып.4. Проблемы языковой нормы. Сб. статей / Ин-т рус. яз. им. В. В. Виноградова РАН - М., 2006. С. 283-294.

Кустова Г. И. Об иллокутивной фразеологии // Смыслы, тексты и другие захватывающие сюжеты. Сб. статей в честь 80-летия И. А. Мельчука. М., 2012. С.349366.

Меликян В.Ю. Проблема статуса и функционирования коммуникем: язык и речь: Монография. Ростов н/Д: Ростиздат, 1999.

Розанова Н.Н. Интонационно-звуковые особенности незнаменательных слов в спонтанной устной речи и их словарное представление // Язык в пространстве речевых культур: Сб. в честь В.Е. Гольдина. Москва-Саратов, 2015. С. 132-145.

Сиротинина О.Б. Современная разговорная речь и ее особенности. М., 1974.

ТСРР — Толковый словарь русской разговорной речи. Вып.1: А — И; отв. ред. Л.П. Крысин. М., 2014;

Толковый словарь русской разговорной речи. Вып. 2: К - О; отв. ред. Л. П. Крысин. М., 2017.

Шаронов И. А. Коммуникативы и методы их описания // Материалы международной конференции «Диалог 2009». Вып. 8(15). М., 2009, С. 543-547.

Шаронов И.А. Поиск и описание коммуникативов на основе Национального корпуса русского языка // Методы когнитивного анализа семантики слова: компьютерно-корпусный подход. М., 2015. С. 141-183.

Шаронов И. А. Коммуникативы в естественных и в художественных диалогах // Экология языка и коммуникативная практика. 2017, № 3. С.114-127.

Шведова Н. Ю. Очерки по синтаксису русской разговорной речи. М., 1960.

Шмелев Д. Н. К вопросу о «производных» служебных частях речи и междометиях // Известия Академии наук СССР. Т. ХХ, Вып. 6. 1961. С.498-505.

Шмелев Д.Н.Н.Ю. Шведова. Очерки по синтаксису русской разговорной речи (рецензия) // Вопросы языкознания. 1961, №1. С. 125-129. 


\section{E. V. Kakorina}

V. V. Vinogradov Russian Language Institute (Russian Academy of Sciences)

(Russia, Moscow)

kakor@yandex.ru

\section{PROBLEMS OF FIXING AND LEXICOGRAPHICAL DESCRIPTION OF COMMUNICATIVES (REVEALED IN THE COURSE OF WORK ON THE EXPLANATORY DICTIONARY OF THE RUSSIAN EVERYDAY SPEECH (EDRES))}

The article is devoted to the study of communicatives and the experience of their description in the modern "Explanatory dictionary of Russian everyday speech" (EDRES). Communicatives are words-utterances, inflexible words or expressions used in dialogues (usually as replies, less often initially). They are stereotypical reactions of the speaker to the preceding remarks or the content of the conversation. From a formal point of view, they are frozen expressions or immutable forms of words (often nouns or verbs) that have developed a new meaning associated with the assessment of the situation or words of the interlocutor in the dialogue. Communicatives are not always fixed in dictionaries, because they are difficult to recognize and identify in the oral dialogue due to their idiomatic semantics, a special syntactic role and specificity of grammatical features. The problems of the description of communicatives in the dictionary are related to the lack of a single view on their morphological (grammatical) properties and the nature of the expressed meaning. Traditionally, communicatives are not distinguished as independent linguistic units. They are described in the dictionary as special values of individual forms or the meaning of any part of speech used in the function of a particle or interjection. We argue that communicatives can become full-fledged units of the dictionary. Their semantics should be described through the indication of the speech act type or the speaker's intention, the nature of the expressed assessment, as well as through the description of the pragmatic conditions for the implementation of their meaning and prosodic features of speech.

Keywords: communicative, illocutive, oral dialogue, lexicographical practice, Russian colloquial speech, explanatory dictionary of everyday speech, semantics and grammar, ways of meaning interpretation.

\section{References}

Baranov A.N., Dobrovol'skii D.O. Frazeologicheskii ob"yasnitel'nyi slovar' russkogo yazyka. [Russian explanatory phraseological dictionary]. Moscow, Eksmo Publ. 2009. 704 p.

Vinogradov V.V. Russkii yazyk. Grammaticheskoye ucheniye o slove [The Russian language. Grammatical doctrine of the word]. Moscow, Leningrad : Uchpedgiz Publ., 1947. $784 \mathrm{p}$.

Zemskaya E. A. [Morphology]. Russkaya razgovornaya rech'. Fonetika. Morfologiya. Leksika. Zhest. [Russian everyday speech. Phonetics. Morphology. Vocabulary. Gesture.]. Moscow, Nauka Publ. 1983. pp. 80-118. 
Kipriyanov V.F. Problema chastei rechi i slova-kommunikativy v sovremennom russkom yazyke [The Problem of Parts of Speech and Communicatives in Modern Russian]. Moscow, MOPI Publ., 1983. 102 p.

Kolokoltseva, T. N. [Anthropocentrism in a Dialogue]. Voprosy stilistiki. [Problems of Stylistics]. Issue 28. Saratov, 1999. pp. 114-125. (in Russ.)

Kreidlin G.E. [Dialogue emphatic responses] // Russkii yazyk segodnya, vyp. 4. Problemy yazykovoi normy. [Russian language today. Issue 4. Problems of language norms / Institute of Russian Language of RAS]. Moscow, 2006. pp. 283-294. (in Russ.)

Kustova G. I. [About illocutive phraseology] // Smysly, teksty i drugie zakhvatyvayushchie syuzhety. [Meanings, texts and other fascinating plots. Festschrift in honor of the 80th anniversary of I. A. Melchuk.]. Moscow, 2012. pp. 349-366. (in Russ.)

Melikyan V.Yu. Problema statusa i funktsionirovaniya kommunikem: yazyk i rech'. [The problem of the status and functioning of the communication: language and speech]. Rostov n/D: Rostizdat, 1999. 200 p.

Rozanova N. N. [Intonational-acoustic features of non-significant words in spontaneous oral speech and their dictionary representation]. Yazyk v prostranstve rechevykh $k u$ l'tur: Sb. v chest' V.Ye. Gol'dina. [Language in the space of speech cultures: Festschrift in honor of V.E. Goldin]. Moscow - Saratov, 2015. pp. 132-145. (in Russ.)

Sirotinina O. B. Sovremennaya razgovornaya rech' i ee osobennosti. [Modern spoken language and its features]. Moscow, 1974. 144 p.

TSRR — Tolkovyi slovar' russkoi razgovornoi rechi. Vyp.1: A-I; otv. red. L.P. Krysin. Tolkovyi slovar' russkoi razgovornoi rechi. Vyp. 2: K-O; otv. red. L.P. Krysin. [Explanatory Dictionary of Russian Conversation. Issue 1: A - I ; ed. by L.P. Krysin]. Moscow, 2014; [Explanatory dictionary of Russian spoken language. Issue 2: $\mathrm{K}-$ O; ed. by L.P. Krysin]. Moscow, 2017.

Sharonov I. A. [Communicatives and methods for their description]. Materialy mezhdunarodnoi konferentsii «Dialog 2009». Vyp. 8(15). [Proc. Int. conference "Dialogue 2009"]. Moscow, 2009, pp. 543-547. (in Russ.)

Sharonov I. A. [Search and description of communication based on the National Corpus of the Russian language] Metody kognitivnogo analiza semantiki slova: komp'yuterno-korpusnyi podkhod. [Methods of cognitive analysis of the semantics of the word: computer corpus approach.]. Moscow, 2015. pp. 141-183. (in Russ.)

Sharonov I. A. [Communicatives in natural and artistic dialogues]. Ekologiya yazyka i kommunikativnaya praktika. [Ecology of language and communicative practice. No. 3]. Moscow, 2017. pp.114-127. (in Russ.)

Shvedova N.Yu. Ocherki po sintaksisu russkoi razgovornoi rechi. [Essays on the syntax of Russian spoken language]. Moscow, Publishing House of the Academy of Sciences of the USSR, 1960. $378 \mathrm{p}$.

Shmelev D. N. [On the question of the "derivatives" of the official parts of speech and interjections] Izvestiya Akademii nauk SSSR. [Izvestia of the Academy of Sciences of the USSR]. T. XX, no. 6. 1961. pp. 498-505.

Shmelev D. N. [Essays on the syntax of Russian spoken language (review)]. Voprosy yazykoznaniya. [Questions of linguistics]. 1961, no. 1. pp. 125-129. 